\title{
The Effect Of Managerial Overconfidence On Leverage
}

Cheonsik Park, Kyungpook National University, South Korea

Hyunseok Kim, Kyungpook National University, South Korea

\begin{abstract}
In this paper, we examine the relationship between managerial overconfidence and leverage. Analyzing a sample of firms listed on Korean Stock Market during the period from 1985 to 2007, we use the average of the past 12 months Business Survey Index (BSI) from Bank of Korea as proxy measure of managerial overconfidence. We find that managers tend to issue more debts when they have overconfidence and this result is consistent with Oliver (2009) and Yu et al. (2006).
\end{abstract}

Keywords: Managerial overconfidence, Leverage, Capital structure

\section{INTRODUCTION}

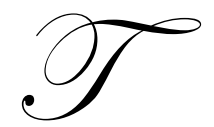

he main contents of capital structure theories are to explore the actual existence of optimal capital structure and finding it. Since the original study by Modigliani and Miller (1958), a plethora of research has been undertaken in attempting to identify the determinants of capital structure. These researches focus on the agency costs, asymmetric information, and so on. And above theories contain implicit assumptions that managers and investors are rational decision maker who want to get maximum utility.

In a different way, many psychological studies already reported that common people tend to have overconfidence (Weinstein, 1980; Alicke, 1985) and this phenomenon is more frequently reveal to managers (Cooper et al., 1988; Landier et al., 2009). Cooper et al. (1988) made a survey about some U.S. managers and they found that managers generally thought the success probability of other firms is only 59\%, but this probability goes up to $81 \%$ when it is involved in their own firms. This suggested that it is popular for managers to be overconfident. But continued survey was showed $66 \%$ of firms having a bad performance. Landier et al. (2009) were surveyed French managers and found $56 \%$ of them thought themselves can survive and only $6 \%$ of them had negative opinion about their future. After 3 years later, the proportions are changed that previous result is increased to $38 \%$ but opposite result is decreased to $17 \%$. Besides, this phenomenon can be captured in maturing firms. Merrow et al. (1981) investigated the investment of equipment in energy industry of U.S. They found that managers are too optimistic about their cost of equipment investment, so they sometimes undervalue the cost. But the actual cost was twice over the valued. Statman et al. (2006) are investigated the managers of other industries and found that all of them have overconfidence about the cost and sales forecasting.

Recently, we have recognized the irrationality of managers and investors which affects the corporate decision making and asset pricing. But, compare to studies about the irrational behavior of investors in financial decision making, not only few studies that irrational behavior of managers but also elementary. In addition, empirical studies of this field are inferior to those of theoretical. Since the researchers could not find appropriate ways to evaluate irrational behavior of managers.

The studies of the irrational act for managers in financial decision making contain distortion of corporate investment and corporate financing. Roll (1986) suggested that managerial overconfidence result in ex-post value destroying merger and acquisition (M\&A). Roll's hubris hypothesis suggests that managers are too optimistic about the performance of their acquisition as they overestimate the benefits of the takeover. He proposed that "If there were no value at all in takeover, why would firms make bids in the first place?" Roll also and analyzed the cause of failures of failed to learn from their own past errors and convince themselves that the valuation is right to the 
combined firm. Like Roll's (1986) previous study, Malmendier and Tate (2005a) showed that overconfident managers are more likely than the rational managers to undertake value-destroying acquisitions. Heaton (2002) showed that financing decisions of overconfident managers are more in the interest of shareholders than rational managers' decisions, and he suggested that overconfident or optimistic managers overestimate net present value of their future cash flows and overinvest when they have free cash flows. Once internal funds are exhausted and firms are financially constrained, they are reluctant to issue new equity because they perceive the stock of their company to be undervalued by the market. Therefore, overconfident managers have a high sensitivity of corporate investment to cash flow. Malmendier and Tate (2005b) found that investment of overconfident managers is more responsive to cash flow than those of rational managers using panel data on personal and corporate investment decisions of Forbes 500 managers. Thus, managerial overconfidence can account for corporate investment distortions. Lin et al. (2005) examined the relationship between managerial overconfidence and investment based on Taiwan listed companies and found the same results. The issue of overconfidence and the impact has on investment decision making reviewed in Englmaier (2007).

Although the studies that irrational behavior of investors in financial decision making have progressed, studies that irrational behavior of managers have tried recently (Shefrin, 2001; Heaton, 2002; Hackbarth, 2008; Oliver, 2009). These based on the assumption that overconfident or optimistic managers have a reduced risk perception and inflated expectations of future profits. Due to the manager's overvaluation of the project, overconfident or optimistic managers prefer to issue debt which pays the coupons rather than issue new equity which shares the future profits of firm with new stockholder. Therefore, managerial overconfidence may induce debt overhang (Shefrin, 2001). Although Shefrin (2001), Heaton (2002) and Hackbarth (2008) suggested the relationship between managerial overconfidence and leverage theoretically, these empirical studies not sufficient. It is reason for hard to measure overconfidence.

In this paper, we examine the empirical relationship between managerial overconfidence and leverage of firms using appropriate proxy variable of managerial overconfidence. The paper is organized as follows. Section 1 is the introduction. Section 2 considers the overconfidence measure and model specifications. Section 3 describes the definition of individual variables and data. Section 4 documents the empirical results. Section 5 is the conclusion with a summary.

\section{OVERCONFIDENCE MEASURE AND MODEL SPECIFICATIONS}

\subsection{Overconfidence measure}

Overconfidence is defined as an overestimation of one's own abilities and outcomes relating to one's personal situation (Langer, 1975). Measuring managerial overconfidence is one of the most difficult and important problems. Quantifying overconfidence is uncertain as there is no directly instrument to measure managerial overconfidence. The proxy variables which were used preceding literatures about managerial overconfidence can be summarized as follows (Jiang et al., 2008).

\subsubsection{Holdings of manager's stock and stock option}

This was proposed first by Malmendier and Tate (2005a, 2005b, 2008). It includes three variables: First, when a manager holds an option of 5years, if the option is more than $67 \%$ in-the-money at some point in year 5 but he does not exercise, he is regarded as overconfident. Second, if a manager holds an option until the last year of its duration, he is regarded as overconfident. Third, if a manager purchases additional firm stock despite their already high exposure to risk, he is regarded as overconfident.

\subsubsection{Perceptions about a manager by outsiders}

This approach may be the most widely used one. It was proposed first by Hayward and Hambrick (1997), they collected some main medias' evaluations about managers and classified them into six kinds and gave every kind an individual point respectively. Malmendier and Tate (2008) amended this measurement. They classified 
presses' valuations into five kinds. Brown and Sarma (2007) adopted the same approach and used ratios to measure. Hribar and Yang (2006) and Jin and Kothari (2005) also used this approach.

\subsubsection{Upward-biased earnings forecasts by managers}

This was proposed first by Lin et al. (2005). Hribar and Yang (2006) and Jiang et al. (2008) also was used this approach in their paper. They argued that overconfident managers were apt to make upward-biased earnings forecasts. They first got FE=Managerial forecast for earnings before tax-Actual earning before tax, and the positive FE denoted upward-biases, or downward-biases. If the numbers of upward-biases are more than that of downwardbiases, the managers are regarded as overconfident.

\subsubsection{Frequency of $M \& A$ made by managers}

This was proposed first by Doukas and Petmezas (2007). They argued that the more confident the manager, the higher frequency the M\&A. They regarded a manager as overconfident if he made at least five M\&A during their study period.

\subsubsection{CEOs' relative compensations}

This was proposed first by Hayward and Hambrick (1997). They argued that the higher the CEO's relative compensation to other managerial, the more important the CEO's position, and consequently they would be apt to be overconfident. They used "CEO cash compensation divided by the second-highest-paid officer" to measure. Similarly, Jiang et al. (2008) also used "CEO cash compensation divided by the first-three-highest-paid officer" in their measurement.

\subsubsection{Firm's recent performance}

This was also proposed first by Hayward and Hambrick (1997). They used "stockholder returns for the twelve months prior to the date used to determine the unaffected stock price divided by the initial stock price" to measure.

\subsubsection{Booming index}

This was proposed first by Oliver (2009). He used proxy managerial overconfidence as the average of the past 12 months Consumer Sentiment Index (CSI) from the University of Michigan from 1978 to 2004. Mefteh and Oliver (2009) used Economic Sentiment Indicator (ESI) from the European Commission from 1995 to 2004. They analyzed the firms listed on French market and subdivided industrial companies, service firms, retail firms, construction firms. A possible maximum and minimum of each index is +100 and -100 . Yu et al. (2006) used firms booming index published by National Bureau of Statistics of China to measure. A possible maximum and minimum of each index is 200 or 0 . If the index was higher than 100 , the manager of a firm that operated in one industry was overconfident.

From these measuring above, we can see that they are more or little subjective. But we have no other choice. Regarding of the availability of data and the special situation of Korea, we use Business Survey Index (BSI) as proxy variable of managerial overconfidence, following Oliver (2009), Mefteh and Oliver (2009) and Yu et al. (2006).

\subsection{Model specifications}

We examine the empirical relationship between managerial overconfidence and leverage of firms using financial structure variables which were used preceding literatures. Rajan and Zingales (1995) investigated the determinants of capital structure for G7's countries and found that market to book ratio (MB), firm size (SIZE), tangibility (TNG) and profitability (PRF) are common variables of the influence on the leverage. Following the study of Rajan and Zingales (1995), we include above variables. And we also include the proxy variable of 
managerial overconfidence (CONF), following Oliver (2009), Mefteh and Oliver (2009), Yu et al. (2006) and Brettel et al. (2008). All the independent variables are lagged one year. This allows the information regarding the determinants of capital structure to be available to managers in the year prior to the observed level of leverage (Mefteh and Oliver, 2009). Therefore, we construct linear regression models which are named 'basic model' as follow:

$$
\begin{aligned}
& \operatorname{BLEV}_{\mathrm{i}, \mathrm{t}}=\alpha_{0}+\alpha_{1} \mathrm{CONF}_{\mathrm{i}, \mathrm{t}-1}+\alpha_{2} \mathrm{MB}_{\mathrm{i}, \mathrm{t}-1}+\alpha_{3} \mathrm{SIZE}_{\mathrm{i}, \mathrm{t}-1}+\alpha_{4} \mathrm{TNG}_{\mathrm{i}, \mathrm{t}-1}+\alpha_{5} \mathrm{PRF}_{\mathrm{i}, \mathrm{t}-1}+\varepsilon_{\mathrm{i}, \mathrm{t}} \\
& \mathrm{MLEV}_{\mathrm{i}, \mathrm{t}}=\alpha_{0}+\alpha_{1} \mathrm{CONF}_{\mathrm{i}, \mathrm{t}-1}+\alpha_{2} \mathrm{MB}_{\mathrm{i}, \mathrm{t}-1}+\alpha_{3} \mathrm{SIZE}_{\mathrm{i}, \mathrm{t}-1}+\alpha_{4} \mathrm{TNG}_{\mathrm{i}, \mathrm{t}-1}+\alpha_{5} \mathrm{PRF}_{\mathrm{i}, \mathrm{t}-1}+\varepsilon_{\mathrm{i}, \mathrm{t}}
\end{aligned}
$$

Oliver (2009) and Yu et al. (2006) added the lagged book-value leverage $\left(\mathrm{BLEV}_{\mathrm{i}, \mathrm{t}-1}\right)$ or the lagged marketvalue leverage $\left(\mathrm{MLEV}_{\mathrm{i}, \mathrm{t}-1}\right)$ to equation [1], [2] for a robustness test. Following Oliver (2009) and Yu et al. (2006), we include each variable to equation [1], [2] as control variable and construct linear regression models which are named 'expansion model' as follow:

$$
\begin{aligned}
& \text { BLEV }_{\mathrm{i}, \mathrm{t}}=\alpha_{0}+\alpha_{1} \mathrm{CONF}_{\mathrm{i}, \mathrm{t}-1}+\alpha_{2} \mathrm{MB}_{\mathrm{i}, \mathrm{t}-1}+\alpha_{3} \mathrm{SIZE}_{\mathrm{i}, \mathrm{t}-1}+\alpha_{4} \mathrm{TNG}_{\mathrm{i}, \mathrm{t}-1}+\alpha_{5} \mathrm{PRF}_{\mathrm{i}, \mathrm{t}-1}+\alpha_{6} \mathrm{BLEV}_{\mathrm{i}, \mathrm{t}-1}+\varepsilon_{\mathrm{i}, \mathrm{t}} \\
& \mathrm{MLEV}_{\mathrm{i}, \mathrm{t}}=\alpha_{0}+\alpha_{1} \mathrm{CONF}_{\mathrm{i}, \mathrm{t}-1}+\alpha_{2} \mathrm{MB}_{\mathrm{i}, \mathrm{t}-1}+\alpha_{3} \mathrm{SIZE}_{\mathrm{i}, \mathrm{t}-1}+\alpha_{4} \mathrm{TNG}_{\mathrm{i}, \mathrm{t}-1}+\alpha_{5} \mathrm{PRF}_{\mathrm{i}, \mathrm{t}-1}+\alpha_{6} \mathrm{MLEV}_{\mathrm{i}, \mathrm{t}-1}+\varepsilon_{\mathrm{i}, \mathrm{t}}
\end{aligned}
$$

In equation [3] and [4], we can estimate the adjustment speed of capital structure. In trade-off theory, the partial adjustment model of capital structure indicates that firms have long run target leverage and so those firms adjust the gap between actual and target leverage each year. Flannery and Rangan (2006), Korajczyk et al. (2007) and Shin (2008) proposed that adjustment speed of book-value and market-value leverage can be measured by $\theta=1-\alpha_{6}$. The adjustment speed of leverage $(\theta)$ is bounded between zero and one. When $\theta$ is near one of these boundaries, it goes rapidly adjusted to the long run target leverage and $\theta$ is near zero, the adjustment is few.

Given that our sample pools cross-sectional with time-series data, leverage can also be affected by macro factors not contained in our empirical model. Therefore, aside from OLS regressions, we also include in the regressions the fixed and the random effects to model the yearly effect and obtain similar results. We only report the results of OLS regressions in Section 4 so as to save space.

\section{DATA AND VARIABLES}

\subsection{Variables}

\subsubsection{Explanatory variables}

\subsubsection{Managerial Overconfidence (CONF)}

We use the average of the past 12 months Business Survey Index (BSI) from Bank of Korea from 1985 to 2007 as proxy for managerial overconfidence (CONF). The Business Survey Index (BSI) is based on a direct survey about manager's current and expected economic conditions. It is also used to check for overall business cycle. The Business Survey Index (BSI) can be measured as follows:

$$
\text { BSI }=\frac{\text { (number of positive answers }- \text { nunmber of negative answers) }}{\text { all of answers }} \times 100+100
$$

The numerical value of Business Survey Index (BSI) has value of 0 to 200. If it has over (under) the 100, it implies that business cycle enters on an expansion (contraction) phase. 


\subsubsection{Dependent variables}

We use two dependent variables and then consider both book-value and market-value of leverage. Book ratios are conceptually different from market ratios. Market values are determined by looking forward in time. Book values are determined by accounting for what has already taken place. In other words book values are generally backward-looking measures, while market values are generally forward-looking measures (Frank and Goyal, 2003). Fama and French (2002), Hovakimian (2006), Welch (2004) and Flannery and Rangan (2006) tend to neglect the importance of the book-value leverage (BLEV), but Shin (2008), Oliver (2009) and Brettel et al. (2008) used both book-value leverage (BLEV) and market-value leverage (MLEV) as dependent variables.

\subsubsection{Book-value leverage (BLEV)}

We use the book-value leverage (BLEV) to dependent variable in most of the empirical tests. Book-value leverage (BLEV) for firm $i$ at time $t$, can be measured as follows:

\subsubsection{Market-value leverage (MLEV)}

$$
\mathrm{BLEV}_{\mathrm{i}, \mathrm{t}}=\frac{\text { book value of total debt }}{\mathrm{i}, \mathrm{t}}
$$

Market-value leverage (MLEV) for firm i at time $t$, can be measured as follows:

$$
\mathrm{MLEV}_{\mathrm{i}, \mathrm{t}}=\frac{\text { book value of total debt }}{\mathrm{i,t}}
$$

\subsubsection{Control variables}

\subsubsection{Market to book ratio (MB)}

We use the market to book ratio (MB) as variable of growth or investment opportunities. Under the tradeoff theory, the market to book ratio (MB) has negatively related to leverage. Long and Malitz (1985) showed that firms with growth opportunities have lower leverage than those facing those facing tangible investments. Low growth firms with tangible can support more debt because of the ability of potential bondholders to estimate underinvestment and to observe and monitor investment decisions. Jensen and Meckling (1976) argued that highly leveraged firms can experience the asset substitution problem and underinvestment problem. Frank and Goyal (2009) argued that if the firms have abundant investment opportunities, their investment opportunities negatively related to leverage. Titman and Wessels (1988) argued that firms with growth opportunities reduce the leverage to avoid the asset substitution problem and underinvestment problem, which could result from the agency conflicts. Under the pecking order theory, the market to book ratio (MB) has positively related to leverage. Myers (1984) argues that retained earnings are better than debt and debt is better than equity. Thus, firms have growth or investment opportunities increase the leverage when invested capitals of the firms exceed retained earnings. Market to book ratio (MB) for firm i at time $t$, can be measured as follows:

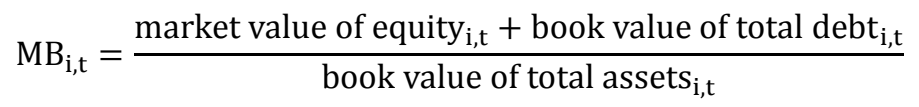

\subsubsection{Firm size (SIZE)}

Under the trade-off theory, firm size (SIZE) has positively related to leverage (Frank and Goyal, 2003). Firm size (SIZE) affects a leverage through the default risk and bankruptcy cost. Flath and Knoeber (1980) and Booth et al. (2001) argue that larger firms can be increased the debt capacity because they can conduct a business diversification more easily and have a lower probability of bankruptcy and volatility of cash flow. Chittenden et al. (1996) argue that larger firms have more leverage because they have lower monitoring costs and then they can reduce the problem of moral hazard and adverse selection. On the other hand, the pecking order theory argues that 
firm size (SIZE) has negatively related to leverage because larger firms have less asymmetry information problem as compared with small firms and then they prefer to issue equity instead of debt (Fama and French, 2002). The natural logarithm of total assets or total sales is commonly considered a proxy for the size of each firm. In this paper, firm size (SIZE) for firm i at time $t$, can be measured as follows:

$$
\operatorname{SIZE}_{i, \mathrm{t}}=\ln \left(\text { total }_{\text {assets }}, \mathrm{t}\right)
$$

\subsubsection{Tangibility (TNG)}

Tangible assets provide better collateral for loans and are expected to support debt since they can be pledged as collateral. As expected the more collateral firms have, the greater the leverage (Frank and Goyal, 2003). If firms have abundant tangible fixed assets and inventories, they have a better collateral value (Scott, 1977). Stulz and Johnson (1985) argue that firms have financed the secured debt can increase their firm value because it can reduce the underinvestment problem. Tangible assets are less subject to informational asymmetries and usually have a greater value than intangible assets in case of bankruptcy (Johnson, 1997). Additionally, the moral hazard risks are reduced when the firm offers tangible assets as collateral, because this constitutes a positive signal to the debt holders (Oliver, 2009). Tangibility (TNG) is related to collateral but it excludes short-term assets. Tangibility (TNG) for firm $i$ at time $t$, can be measured as follows:

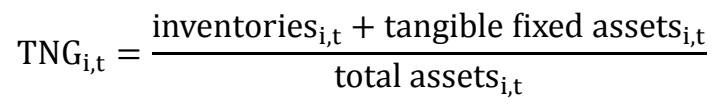

\subsubsection{Firm Profitability (PRF)}

Under the trade-off theory, firms with high profitability (PRF) have low bankruptcy cost and high tax shield effect and so they will use more debt. The pecking order theory predicts that more profitable firms will have less leverage. Myers and Majluf (1984) argue that firms with high profitability (PRF) have low leverage because they are more likely that financing would be from internal sources rather than external sources. Titman and Wessels (1988) and Rajan and Zingales (1995) also argue that the firm profitability (PRF) is negatively related to leverage. On the other hand, Jensen (1986) argues that firm managers of the highly profitable firms may be tempted to overspend their fee cash flow, so high debt is useful to control the overspending problem. The firm profitability (PRF) for firm i at time $t$, can be measured as follows:

$$
\mathrm{PRF}_{\mathrm{i}, \mathrm{t}}=\frac{\text { EBITDA }_{\mathrm{i}, \mathrm{t}}}{\text { total }_{\text {assets }}}
$$

\subsection{Data}

The sample consists of firms listed on Korean stock market during the period from 1985 to 2007. Financial firms are excluded because they are subjected to legal regulations regarding capital structure. We also eliminate some data which did not maintain their settlement term as December. All the accounting and financial statement data are sourced from the Korea Information Service (KIS-value). The Business Survey Index as proxy variable of managerial overconfidence (CONF) is sourced from Bank of Korea. Based on this procedure, our data include total 516 firms or 10,848 firm-years. Descriptive statistics for these firms are provided in Table 1.

Table 1: Descriptive statistics

\begin{tabular}{|c|c|c|c|c|c|c|c|}
\hline & BLEV & MLEV & CONF & MB & SIZE & TNG & PRF \\
\hline Mean & 0.6228 & 0.7152 & 95.4523 & 0.9372 & 25.5780 & 0.3562 & 0.0896 \\
\hline Standard deviation & 0.2357 & 0.2370 & 16.2414 & 0.3717 & 1.5413 & 0.1692 & 0.0688 \\
\hline Maximum & 4.7341 & 1.0000 & 124.0000 & 6.8557 & 31.8089 & 0.9189 & 0.5648 \\
\hline Minimum & 0.0260 & 0.0246 & 57.2500 & 0.2118 & 18.0550 & 0.0000 & -0.4680 \\
\hline
\end{tabular}


As shown in Table 1, the average value of book-value leverage (BLEV) over the sample period is $62.28 \%$ and the market-value leverage (MLEV) over the sample period is $71.52 \%$. Based on book values, on average firms have 62.28\% leverage which is higher than Son and Lee (2007) who report leverage at $47.40 \%$ and Shin (2008) who report leverage at $56.17 \%$. Based on market values, on average firms have $71.52 \%$ leverage which is higher than Son and Lee (2007) who report leverage at 53.29\% and Shin (2008) who report leverage at $58.83 \%$. The average value of managerial overconfidence (CONF) over the sample period is approximately 95 and the maximum value is 124.00 the minimum value is 57.25 . The average value of market to book ratio (MB) is 0.9372 , firm size (SIZE) is 25.5870 , tangibility (TNG) is 0.3562 and firm profitability (PRF) is 0.0896 .

\section{EMPIRICAL RESULTS}

\subsection{Pearson correlation coefficient}

Table 2: Pearson Correlation Coefficients

\begin{tabular}{|c|c|c|c|c|c|c|c|}
\hline & BLEV & MLEV & CONF & MB & SIZE & TNG & PRF \\
\hline BLEV & 1.000 & & & & & \\
\hline MLEV & $\begin{array}{c}0.6233 * * * \\
(0.0000)\end{array}$ & 1.000 & & & & \\
\hline CONF & $\begin{array}{c}0.1023 * * * \\
(0.0000)\end{array}$ & $\begin{array}{c}0.0269 * * \\
(0.0148)\end{array}$ & 1.000 & & & \\
\hline MB & $\begin{array}{c}0.1898^{* * *} \\
(0.0000)\end{array}$ & $\begin{array}{c}-0.3053 * * * \\
(0.0000)\end{array}$ & $\begin{array}{c}0.0048 \\
(0.6579)\end{array}$ & 1.000 & & & \\
\hline SIZE & $\begin{array}{c}-0.0248 * * \\
(0.0116)\end{array}$ & $\begin{array}{c}-0.1340 * * * \\
(0.0000)\end{array}$ & $\begin{array}{c}-0.0947 * * \\
(0.0000)\end{array}$ & $\begin{array}{c}0.0855^{* * *} \\
(0.0000)\end{array}$ & 1.000 & & \\
\hline TNG & $\begin{array}{c}0.0645 * * * \\
(0.0000)\end{array}$ & $\begin{array}{c}0.1227 * * * \\
(0.0000)\end{array}$ & $\begin{array}{c}0.0056 \\
(0.6096)\end{array}$ & $\begin{array}{c}-0.0869 * * * \\
(0.0000)\end{array}$ & $\begin{array}{c}0.1311 * * * \\
(0.0000)\end{array}$ & 1.000 & \\
\hline PRF & $\begin{array}{c}-0.0822 * * * \\
(0.0000)\end{array}$ & $\begin{array}{c}0.0096 \\
(0.3264)\end{array}$ & $\begin{array}{c}0.0782 * * * \\
(0.0000)\end{array}$ & $\begin{array}{c}-0.0404 * * * \\
(0.0001)\end{array}$ & $\begin{array}{c}-0.0788 * * * \\
(0.0000)\end{array}$ & $\begin{array}{c}-0.0068 \\
(0.4832)\end{array}$ & 1.000 \\
\hline
\end{tabular}

Table 2 reports results of correlation between variables. The correlation between managerial overconfidence (CONF) and book-value leverage (BLEV) are positive and significant at $1 \%$ level and the correlation between managerial overconfidence (CONF) and market-value leverage (MLEV) are positive and significant at 5\% level. The correlation between market to book ratio (MB) and book-value leverage (BLEV) are positive and significant at the $1 \%$ level and the correlation between market to book ratio (MB) and market-value leverage (MLEV) are negative and significant at 1\% level. The correlation between firm size (SIZE) and book-value leverage (BLEV) are negative and significant at 5\% level and the correlation between firm size (SIZE) and marketvalue leverage (MLEV) are negative and significant at $1 \%$ level. The correlation between tangibility (TNG) and book-value leverage (BLEV) are positive and significant at $1 \%$ level and the correlation between tangibility (TNG) and market-value leverage (MLEV) are also positive and significant at $1 \%$ level. The correlation between firm profitability (PRF) and book-value leverage (BLEV) are negative and significant at $1 \%$ level but the correlation between firm profitability (PRF) and market-value leverage (MLEV) is not statistically significant.

\subsection{The results of multiple regression analysis}

\subsubsection{The effect of managerial overconfidence on book-value leverage}

The results of regression equation [1] and [3] whose dependent variables are book-value leverage (BLEV) and explanatory variables are managerial overconfidence (CONF) are shown in Table 3. 
Table 3: The effect of managerial overconfidence on book-value leverage

\begin{tabular}{|c|c|c|c|c|c|}
\hline \multicolumn{2}{|c|}{ Classification } & \multicolumn{2}{|c|}{ Basic model } & \multicolumn{2}{|c|}{ Expansion model } \\
\hline Variable & & Coefficient & VIF & Coefficient & VIF \\
\hline CONF & $\alpha_{1}$ & $\begin{array}{c}0.0022 * * * \\
(9.0461)\end{array}$ & 1.0282 & $\begin{array}{c}0.0007 * * * \\
(4.0699)\end{array}$ & 1.0537 \\
\hline MB & $\alpha_{2}$ & $\begin{array}{c}0.0993 * * * \\
(11.7345)\end{array}$ & 1.0550 & $\begin{array}{c}0.0525 * * * \\
(8.4335)\end{array}$ & 1.0780 \\
\hline SIZE & $\alpha_{3}$ & $\begin{array}{c}0.0116^{* * *} * \\
(3.9424)\end{array}$ & 1.0671 & $\begin{array}{c}0.0064 * * * \\
(3.0089)\end{array}$ & 1.0688 \\
\hline TNG & $\alpha_{4}$ & $\begin{array}{c}0.1476 * * * \\
(6.5255)\end{array}$ & 1.0259 & $\begin{array}{c}0.0516^{* * *} \\
(3.1289)\end{array}$ & 1.0384 \\
\hline PRF & $\alpha_{5}$ & $\begin{array}{c}-0.3897 * * * \\
(-6.6699)\end{array}$ & 1.0503 & $\begin{array}{c}-0.2108 * * * \\
(-4.9611)\end{array}$ & 1.0561 \\
\hline Adjustment speed $(\theta)$ & $1-\alpha_{6}$ & & & 0.3842 & \\
\hline \multicolumn{2}{|l|}{ Adjusted $\mathrm{R}^{2}$} & \multicolumn{2}{|c|}{0.0841} & \multicolumn{2}{|c|}{0.5251} \\
\hline
\end{tabular}

( ): indicate t-Statistic, *,**, and *** indicate significant at the $10 \%, 5 \%$, and $1 \%$ level respectively.

In the basic model, the coefficient on the variable of managerial overconfidence (CONF) is positive and significant. This result implies that when the variable of managerial overconfidence (CONF) is higher, firms have higher leverage. "This supports the notion that overconfidence or optimism causes managers to overestimate the future return to their investment project and underestimate the risk of decision outcomes. This leads corporate managers to use more debt financing when they are overconfident (Oliver, 2009)." This result is consistent with Oliver (2009) and Yu et al. (2006).

The market to book ratio (MB) as a proxy for growth or investment opportunities is positively and significantly related to book-value leverage (BLEV) at $1 \%$ level. This is supported by pecking order theory and consistent with Welch (2004), Hovakimian (2006), Flannery and Rangan (2006) and Shin (2008). The firm size (SIZE) is positively and significantly related to book-value leverage (BLEV) at $1 \%$ level. This is supported by tradeoff theory and consistent with Flath and Knoeber (1980), Booth et al. (2001) and Chittenden et al. (1996). The tangibility (TNG) as a proxy for collateral value is positively and significantly related to book-value leverage (BLEV) at $1 \%$ level. This also supports that firms with higher tangibility are likely to have lower informational asymmetries, as well as lower bankruptcy risk and moral hazard risks. This is consistent with Scott (1977), Stulz and Johnson (1985), Johnson (1997), Frank and Goyal (2003), Shin (2008) and Oliver (2009). The firm profitability (PRF) is negatively and significantly related to book-value leverage (BLEV) at $1 \%$ level. This is supported by pecking order theory and consistent with Myers and Majluf (1984), Titman and Wessels (1988), Rajan and Zingales (1995) and Shin (2008).

In the expansion model which added the lagged term of the book-value leverage $\left(\mathrm{BLEV}_{\mathrm{t}-1}\right)$ to the basic model, the coefficient on the variable of managerial overconfidence (CONF) is positive and significant. This result implies that when the variable of managerial overconfidence (CONF) is higher, firms have higher leverage. It is similar for market to book ratio (MB), firm size (SIZE), tangibility (TNG) and profitability (PRF) to affect on the book-value leverage (BLEV). The coefficient on the lagged term of the book-value leverage $\left(\mathrm{BLEV}_{\mathrm{t}-1}\right)$ is positive and significant at $1 \%$ level. And also the numerical value of coefficient is 0.6158 and then we can estimate the adjustment speed of book-value leverage at 0.3842 which is measured by 'one minus the numerical value of coefficient on the lagged term of the book-value leverage $\left(\mathrm{BLEV}_{\mathrm{t}-1}\right)^{\prime}$.

\subsubsection{The effect of managerial overconfidence on market-value leverage}

The results of regression equation [2] and [4] whose dependent variables are market-value leverage (MLEV) and explanatory variables are managerial overconfidence (CONF) are shown in Table 4. 
Table 4: The effect of managerial overconfidence on market-value leverage

MLEV $_{\mathrm{i}, \mathrm{t}}=\alpha_{0}+\alpha_{1} \mathrm{CONF}_{\mathrm{i}, \mathrm{t}-1}+\alpha_{2} \mathrm{MB}_{\mathrm{i}, \mathrm{t}-1}+\alpha_{3} \mathrm{SIZE}_{\mathrm{i}, \mathrm{t}-1}+\alpha_{4} \mathrm{TNG}_{\mathrm{i}, \mathrm{t}-1}+\alpha_{5} \mathrm{PRF}_{\mathrm{i}, \mathrm{t}-1}+\varepsilon_{\mathrm{i}, \mathrm{t}}$

[2]

$\mathrm{MLEV}_{\mathrm{i}, \mathrm{t}}=\alpha_{0}+\alpha_{1} \mathrm{CONF}_{\mathrm{i}, \mathrm{t}-1}+\alpha_{2} \mathrm{MB}_{\mathrm{i}, \mathrm{t}-1}+\alpha_{3} \mathrm{SIZE}_{\mathrm{i}, \mathrm{t}-1}+\alpha_{4} \mathrm{TNG}_{\mathrm{i}, \mathrm{t}-1}+\alpha_{5} \mathrm{PRF}_{\mathrm{i}, \mathrm{t}-1}+\alpha_{6} \mathrm{MLEV}_{\mathrm{i}, \mathrm{t}-1}+\varepsilon_{\mathrm{i}, \mathrm{t}}$

\begin{tabular}{|c|c|c|c|c|c|}
\hline \multicolumn{2}{|c|}{ Classification } & \multicolumn{2}{|c|}{ Basic model } & \multicolumn{2}{|c|}{ Expansion model } \\
\hline Variable & & Coefficient & VIF & Coefficient & VIF \\
\hline CONF & $\alpha_{1}$ & $\begin{array}{c}0.0017 * * * \\
(6.8613)\end{array}$ & 1.0282 & $\begin{array}{c}-0.0000 \\
(-0.3345)\end{array}$ & 1.0518 \\
\hline MB & $\alpha_{2}$ & $\begin{array}{c}-0.1353 * * * \\
(-15.8801)\end{array}$ & 1.0550 & $\begin{array}{c}-0.0544 * * * \\
(-11.1165)\end{array}$ & 1.1011 \\
\hline SIZE & $\alpha_{3}$ & $\begin{array}{c}0.0070 * * \\
(2.3459)\end{array}$ & 1.0671 & $\begin{array}{c}0.0008 \\
(0.4877)\end{array}$ & 1.0689 \\
\hline TNG & $\alpha_{4}$ & $\begin{array}{c}0.2008 * * * \\
(8.8149) \\
\end{array}$ & 1.0259 & $\begin{array}{c}0.0285^{* *} \\
(2.2136) \\
\end{array}$ & 1.0526 \\
\hline PRF & $\alpha_{5}$ & $\begin{array}{c}-0.3780 * * * \\
(-6.4251)\end{array}$ & 1.0503 & $\begin{array}{c}-0.1689 * * * \\
(-5.1184)\end{array}$ & 1.0557 \\
\hline Adjustment speed $(\theta)$ & $1-\alpha_{6}$ & & & 0.1804 & \\
\hline \multicolumn{2}{|l|}{ Adjusted $\mathrm{R}^{2}$} & \multicolumn{2}{|c|}{0.1396} & \multicolumn{2}{|c|}{0.7332} \\
\hline
\end{tabular}

( ): indicate t-Statistic, $*, * *$, and $* * *$ indicate significant at the $10 \%, 5 \%$, and $1 \%$ level respectively

In the basic model, the coefficient on the variable of managerial overconfidence (CONF) is positive and significant. This result implies that when the variable of managerial overconfidence (CONF) is higher, firms have higher leverage. This is consistent with Oliver (2009) and Yu et al. (2006).

The market to book ratio (MB) as a proxy for growth or investment opportunities is negatively and significantly related to market-value leverage (MLEV) at $1 \%$ level. This result implies that firms have growth or investment opportunities decrease the leverage and consistent with the trade-off theory. The firm size (SIZE) is positively and significantly related to market-value leverage (MLEV) at 5\% level. This is supported by trade-off theory and consistent with Flath and Knoeber (1980), Booth et al. (2001) and Chittenden et al. (1996). The tangibility (TNG) as a proxy for collateral value is positively and significantly related to market-value leverage (MLEV) at 1\% level. This is consistent with Scott (1977), Stulz and Johnson (1985), Johnson (1997), Frank and Goyal (2003), Shin (2008) and Oliver (2009). The firm profitability (PRF) is negatively and significantly related to market-value leverage (MLEV) at $1 \%$ level. This is supported by pecking order theory and consistent with Myers and Majluf (1984), Titman and Wessels (1988), Rajan and Zingales (1995) and Shin (2008).

In the expansion model which added the lagged term of the market-value leverage $\left(\mathrm{MLEV}_{\mathrm{t}-1}\right)$ to the basic model, the coefficient on the variable of managerial overconfidence (CONF) is not significant. It is similar for market to book ratio (MB), firm size (SIZE), tangibility (TNG) and profitability (PRF) to affect on the market-value leverage (MLEV). The coefficient on the lagged term of the market-value leverage $\left(\mathrm{MLEV}_{\mathrm{t}-1}\right)$ is positive and significant at $1 \%$ level. And also the numerical value of coefficient is 0.8196 and then we can estimate the adjustment speed of market-value leverage at 0.1804 which is measured by 'one minus the numerical value of coefficient on the lagged term of the market-value leverage $\left(\mathrm{MLEV}_{\mathrm{t}-1}\right)$ '.

\section{CONCLUSION}

In this paper, we examine the empirical relationship between managerial overconfidence and leverage of firms listed on Korean Stock Market during the period from 1985 to 2007. Following Oliver (2009), Mefteh and Oliver (2009) and Yu et al. (2006), we use the Business Survey Index (BSI) as proxy measure of managerial overconfidence. The model specifications and main results of this study can be summarized as follows.

First, we construct the basic models whose dependent variable is leverage and explanatory variable is managerial overconfidence (CONF) and control variables are market to book ratio (MB), firm size (SIZE), tangibility (TNG) and profitability (PRF), following Rajan and Zingales (1995), Oliver (2009) and Yu et al. (2006). In the basic model, managerial overconfidence (CONF) is positively and significantly related to both book-value 
leverage (BLEV) and market-value leverage (MLEV). All the control variables (MB, SIZE, TNG, PRF) are significantly related to both book-value leverage (BLEV) and market-value leverage (MLEV).

Second, we construct the expansion model which added the lagged term of the leverage the basic model. In the expansion model, managerial overconfidence (CONF) is significantly positive to book-value leverage (BLEV), but not significant market-value leverage (MLEV). All the control variables (MB, SIZE, TNG, PRF) are significantly related to book-value leverage (BLEV) and most control variables (MB, TNG, PRF) are significantly related to market-value leverage (MLEV). We estimate also the adjustment speed of book-value leverage at 0.3842 and the adjustment speed of market-value leverage at 0.1804 .

Conclusively, managerial overconfidence (CONF) is significantly related to leverage except one case of the expansion model. These results imply that managerial overconfidence may lead to increase leverage and consistent with Oliver (2009) and Yu et al. (2006).

\section{AUTHOR INFORMATION}

Cheonsik Park, Ph.D. is a professor of finance at School of Business Administration, Kyungpook National University. He earned his M.A. in finance at Seoul National University and Ph.D. in finance at Kyungpook National University in Korea. He has taught for twenty-three years in the field of financial management including Banking, Financial Markets, Corporate Finance, Portfolio Management and Financial Derivatives. His primary researches are Risk Management and Financial Institution Management.

Hyunseok Kim, M.A. (E-mail address: khs8319@naver.com) is a graduate student of finance at School of Business Administration, Kyungpook National University. He earned his M.A. in finance at Kyungpook National University in Korea. His research interests include Financial Derivatives, Behavioral Corporate Finance and Risk Management. He passed the examination of the Financial Risk Manager from Global Association of Risk Professional (GARP) and Resistered Fund Manager from the Korea Financial Investment Association.

\section{REFERENCES}

1. Alicke, M. D. (1985). "Global self-evaluation as determined by the desirability and controllability of trait adjectives," Journal of Personality and Social Psychology 49, 1621-1630.

2. Booth, L., V. Aivazian, A. Demirguc-Kunt, and V. Maksimovic, (2001). "Capital structure in developing countries," Journal of Finance 56, 87-130.

3. Brettel M., M. Kasch, and A. Mueller, (2008). "CFO overconfidence, optimism and corporate financing," Working Paper.

4. Brown, R. and N. Sarma, (2007). "CEO overconfidence, CEO dominance and corporate acquisitions," Journal of Economics and Business 59(5), 358-379.

5. Chittenden, F., G. Hall, and P. Hutchinson, (1996). "Small firm growth, access to capital markets and financial structure: Review of issues and an empirical investigation," Small Business Economics 8, 59-67.

6. Cooper, A. C., C. Y. Woo, and W. C. Dunkelberg, (1988). "Entrepreneurs' perceived chances for success," Journal of Business Venturing 3, 97-108.

7. Doukas, J. A. and D. Petmezas, (2007). “Acquisitions, overconfident managers and self-attribution bias," European Financial Management 13(3), 531-577.

8. $\quad$ Englmaier, F. (2007). "A brief survey on overconfidence," Journal of Behavioral Finance.

9. Fama, E. F. and K. R. French, (2002). "Testing trade-off and pecking order predictions about dividends and debt," Review of Financial Studies 15, 1-33.

10. Flannery, M. J. and K. P. Rangan, (2006). "Partial adjustment toward target capital structures," Journal of Financial Economics 79(3), 469-506.

11. Flath, D. and C. R. Knoeber, (1980). "Taxes, failure costs and optimal industry capital structure: An empirical test," Journal of Finance 35, 315-342.

12. Frank, M. Z. and V. K. Goyal, (2003). "Testing the pecking order theory of capital structure," Journal of Financial Economics 67(2), 217-248. 
13. Frank, M. Z. and V. K. Goyal, (2009). "Capital structure decisions: Which factors are reliably important?," Financial Management 38(1), 1-37.

14. Hackbarth, D. (2008). "Managerial traits and capital structure decisions," Journal of Financial and Quantitative Analysis 4, 843-881.

15. Hayward, M. L. A. and D. C. Hambrick, (1997). "Explaining the premiums paid for large acquisitions: Evidence of CEO hubris," Administrative Science Quarterly 42(1), 103-127.

16. Heaton, J. B. (2002). "Managerial optimism and corporate finance," Financial Management 31, 33-45.

17. Hovakimian, A. (2006). "Are observed capital structures determined by equity market timing?," Journal of Financial and Quantitative Analysis 41(1), 221-243.

18. Hribar, P. and H. Yang, (2006). "CEO confidence, management earnings forecasts and earnings management," Working Paper.

19. Jensen, M. C. (1986). "Agency costs of free cash flows, corporate finance and takeovers," American Economic Review 76(2), 323-329.

20. Jensen, M. C. and W. H. Meckling, (1976). "Theory of the firm: Managerial behavior, agency costs and ownership structure," Journal of Financial Economics 3, 305-360.

21. Jiang, F., M. Zhang, and Z. Liu, (2008). "Managerial overconfidence, diversification and firm risk," Working Paper.

22. Johnson, A. S. (1997). "An empirical analysis of the determinants of corporate debt ownership structure," Journal of Financial and Quantitative Analysis 32, 47-69.

23. Jin, L. and S. P. Kothari, (2005). "Determinants of management ownership of unrestricted equity: Overconfidence versus tax explanations," Working Paper.

24. Korajczyk, R. A., X. Wu, and C. K. A. Yeung, (2007). "Initial growth status and corporate capital structure," Working Paper.

25. Landier, A. and D. Thesmar, (2009). "Financial contracting with optimistic entrepreneurs: theory and evidence," Review of Financial Studies 22, 117-150.

26. Langer, E. (1975). "The illusion of control," Journal of Personality and Social Psychology 32, 311-328.

27. Lin, Y., S. Hu, and M. Chen, (2005). "Managerial optimism and corporate investment: Some empirical evidence from Taiwan," Pacific-Basin Finance Journal 13(5), 523-546.

28. Long, M. S. and I. B. Malitz, (1985). "Investment patterns and financial leverage," Corporate capital structures in the United States, The University of Chicago Press, 353-377.

29. Malmendier, U. and G. Tate, (2005a). "Does overconfidence affect corporate investment? CEO overconfidence measures revisited," European Financial Management 11(5), 649-659.

30. Malmendier, U. and G. Tate, (2005b). "CEO overconfidence and corporate investment," Journal of Finance 60, 2661-2700.

31. Malmendier, U. and G. Tate, (2008). "Who makes acquisitions? CEO overconfidence and the market's reaction," Journal of Financial Economics 89(1), 20-43.

32. Mefteh, S. and B. R. Oliver, (2009). "Capital structure choice: The influence of sentiment in France," International Journal of Behavioural Accounting and Finance forthcoming.

33. Merrow, E. D., K. E. Phillips, and C. W. Myers, (1981). "Understanding cost growth and performance shortfalls in pioneer plants," Rand Corporation.

34. Modigliani, F. and M. H. Miller, (1958). "The cost of capital, corporation finance and the theory of investment," American Economic Review 48, 261-297.

35. Myers, S. C. and N. S. Majluf, (1984). "Corporate financing and investment decisions when firms have information that investors do not have," Journal of Financial Economics 13(2), 187-221.

36. Oliver, B. R. (2009). "The impact of market sentiment on capital structures in the US," International Journal of Behavioural Accounting and Finance forthcoming.

37. Rajan, R. G. and L. Zingales, (1995). "What do we know about capital structure? Some evidence from international data," Journal of Finance 50(5), 1421-1460.

38. Roll, R. (1986). "The hubris hypothesis of corporate takeovers," Journal of Business 59(2), 197-216.

39. Scott, J. H. Jr. (1977). "Bankruptcy, secured debt and optimal capital structure," Journal of Finance 32, 1-19.

40. Shefrin, H. (2001). "Behavioral corporate finance," Journal of Applied Corporate Finance 14, 113-126.

41. Shin, M. S. (2008). "The effects of market timing and initial growth status on adjustment speed capital structure,” The Korean Journal of Financial Engineering 7(1), 143-170. (written in Korean) 
42. Son, S. T. and Y. G. Lee, (2007). "Determinants of capital structure in KOSDAQ firms," The Korean Journal of Financial Management 24(1), 109-147. (written in Korean)

43. Statman, M., S. Thorley, and K. Vorkink, (2006). "Investor overconfidence and trading volume," The Review of Financial Studies 19(4), 1531-1565.

44. Stulz, R. M. and H. Johnson, (1985). "An analysis of secured debt," Journal of financial economics 14, 2138 .

45. Titman, S. and R. Wessels, (1988). "The determinants of capital structure choice," Journal of Finance 43, 119.

46. Yu, M., X. Xia, and Z. Zou, (2006). "The relationship between manager's overconfidence and enterprises' radical behavior in incurring debts," Managing World 8, 104-125.

47. Weinstein, N. (1980). "Unrealistic optimism about future life events," Journal of Personality and Social Psychology 39, 806-820.

48. Welch, I. (2004). "Capital structure and stock return," Journal of Political Economy 112, 106-131. 